\title{
Impact of Cement Production on soil Heavy Metals and Nutrients Uptake of Elephant Grass (Pennisetum Purpureum) Grown within 2km Radius of cement Factory in South West Nigeria
}

\section{Omotosho Mohammed Soladoye ${ }^{1}$, Ayinde Kaseem Olusola ${ }^{2}$, Feyisola Roseline Tolulope $^{3}$, Ayeni Leye Samuel ${ }^{4}$, Saliyu Mutiu ${ }^{5}$}

1,3 Department of Plant Science, Olabisi Onabanjo University Ago-Iwoye, Ogun State Nigeria

${ }^{4,5}$ Department of Agricultural Science, Adeyemi College of Education, Ondo, Ondo State, Nigeria

\begin{abstract}
The study investigated the impact of cement production around cement factory at Ewekoro, South West Nigeria within two kilometer radius to the factory on nutrients uptake by Elephant grass. Elephant grass was sampled at 500, 1000, 1500 and $2000 \mathrm{~m}$. Sampling was carried out in wet and dry seasons for two years (2015 and 2016). Samples were subjected to Laboratory analysis. The parameters determined in the plant samples were $\mathrm{Ca}, \mathrm{Mg}, \mathrm{Na}, \mathrm{K}$, total $\mathrm{N}, \mathrm{Cu}, \mathrm{Zn}, \mathrm{Fe}, \mathrm{Mn}, \mathrm{Pb}, \mathrm{Ni}, \mathrm{Cr}$, and $\mathrm{Cd}$. Generally, there was a decrease in all the nutrients uptake by the grass as the distance from the factory increased during the dry season. $\mathrm{Mg}$ in the plant tissue initially decreased to a distance of $1500 \mathrm{~m}$ and was later observed to increase $2000 \mathrm{~m}$ from the factory. Calcium and Zn concentration was found to be highest in Pennisetum purpureum. Mean composition of micro-nutrients revealed higher concentration of Zinc ranged from $6.31 \pm 0.36$ to $42.04 \pm 2.71 \mathrm{mg} / \mathrm{kg}$ and lower concentration from $6.42 \pm 0.78$ to $10.44 \pm 3.39 \mathrm{mg} / \mathrm{kg}$ respectively. Results of heavy metal concentration revealed a range from $2.67 \pm 0.24$ to $6.11 \pm 0.77 \mathrm{mg} / \mathrm{kg}$ for Lead while the mean values obtained ranged from $0.04 \pm 0.01$ to $5.5 \mathrm{mg} / \mathrm{kg}$. Results obtained from analysis of Pennisetum purpureum showed Calcium to be the most abundant micronutrients with a mean concentration ranged from $2.99 \%$ to $5.13 \%$ while the mean value recorded at Ewekoro showed a range between $0.19 \%$ and $0.36 \%$. Mean Nitrogen content ranged between 1.26 and $2.47 \%$ at Ewekoro.
\end{abstract}

Keyword-nutrient uptake, heavy metals, micronutrients, pollution.

\section{INTRODUCTION}

Pollution is the introduction of contaminants into a natural setting to cause instability, disorder, harm or discomfort to the ecosystem (Blacksmith Institute, 2007). Soil, water and air can be polluted by metals. Plants growing in a polluted environment are known to accumulate the toxic substances that can cause sicknesses to human body (Alloway, 1995). Plants normally absorb whatever soil nutrient that is available to them. Even the specks of dust that contaminate soils are absorbed by the plants and later hinder the normal functioning of the leaves, which ultimately results in crop low yield (Alloway, 1995). A reasonable amount of heavy metals are absorbed by the plants from the contaminated soil which are later absorbed by animals and man through the consumption of the plant products by livestock and man.

Accumulation of heavy metals by plant roots, stems and leaves grown in polluted soils have been reported by Okoronkwo et al. (2005). Elephant grass (Pennisetum purpureum Schumach). is a dominant tall tropical grass (CABI, 2014) with high yield and can tolerate a range of climatic conditions. It is also a valuable forage crop (CABI, 2014; FAO, 2015). Cattle and buffaloes cherish the plant. Elephant grass can be grazed, provided it is often kept at the lush vegetative stage. Meanwhile,livestock tend to feed only 
on the younger leaves (FAO, 2015). Elephant grass is a multipurpose plant. Apart from being animal feeds, its culms can also be used to build fences and thatches. Therefore, this study aims to assess the impact of cement particulate contamination on nutrient uptake and yield of Elephant grass (Pennisetum purpureum)within $2 \mathrm{~km}$ radius cement factory

\section{MATERIALS AND METHOD}

Elephant grass was the pre-dominant plant that animal feeds on in the study area. It was randomly collected at 500, 1000, 1500 and $2000 \mathrm{~m}$ interval. The four treatments were replicated three times i.e. from each location three plants were bulked in three places. Collection was carried out in wet and dry seasons for two years (2015 and 2016). Samples collected were subjected to Laboratory analysis using standard procedure. Determination of the composition of micronutrients such as $\mathrm{Ca}, \mathrm{Mg}, \mathrm{Na}, \mathrm{K}, \mathrm{N}, \mathrm{Cu}, \mathrm{Zn}, \mathrm{Fe}$, and $\mathrm{Mn}$ in the plant samples were carried out while the soil samples were analyzed to determine the level of the presence of heavy metals such as $\mathrm{Pb}, \mathrm{Ni}, \mathrm{Cr}$, and $\mathrm{Cd}$.
The soil samples were collected at different places, dried and $2 \mathrm{~mm}$ sieved. The leaf samples were oven-dried and digested with Nitric/Perchloric acid mixture (2:1). The cations, $(\mathrm{Ca}, \mathrm{Mg}, \mathrm{Na}, \mathrm{K})$, were analyzed by Atomic Absorption Spectrophotometer (AAS) through flame ionization method (Chapman and Pratt, 1961), total Nitrogen in the plants was determined by Kjeldahl digestion and the Nitrogen determined colourimetrically (Bremner, 1996). Total P was determined colourimetrically by the Vanadomolybdenum yellow procedure (Murphy and Riley, 1962). Micro-nutrients $(\mathrm{Cu}, \mathrm{Zn}, \mathrm{Fe}$ and $\mathrm{Mn})$ and heavy metals $(\mathrm{Pb}$, $\mathrm{Ni}, \mathrm{Cr}$, and $\mathrm{Cd}$ ) were also determined with AAS from the digest above.

\section{Statistical Analysis}

Statistical analysis of the data collected was carried out using the SAS software 2014 version. Parameters evaluated are mean values of data generated from the field using Duncan Multiple range Test at 5\% significant level.

The chemical composition of cement is shown in table 1 below.

\section{RESULT}

Table 1: Chemical components of Cement.

\begin{tabular}{llll}
\hline Components & Producer $\mathrm{L}(\%)$ & Producer $\mathrm{H}(\%)$ & Producer T (\%) \\
\cline { 2 - 4 } $\mathrm{Na}_{2} \mathrm{O}$ & & & \\
$\mathrm{MgO}$ & 0.11 & 0.11 & 0.11 \\
$\mathrm{Al}_{2} \mathrm{O}_{3}$ & 1.60 & 2.10 & 3.82 \\
$\mathrm{SiO}_{2}$ & 4.19 & 4.31 & 4.29 \\
$\mathrm{P}_{2} \mathrm{O}_{5}$ & 18.59 & 19.84 & 19.31 \\
$\mathrm{SO}_{3}$ & 0.58 & 0.09 & 0.09 \\
$\mathrm{Cl}$ & 3.31 & 2.96 & 3.26 \\
$\mathrm{~K}_{2} \mathrm{O}$ & 0.04 & 0.05 & 0.02 \\
$\mathrm{CaO}$ & 1.16 & 0.59 & 0.53 \\
$\mathrm{TiO}_{2}$ & 55.62 & 62.05 & 56.62 \\
$\mathrm{MnO}$ & 0.21 & 0.26 & 0.21 \\
$\mathrm{Fe}_{2} \mathrm{O}_{3}$ & 0.03 & 0.17 & 0.38 \\
\hline
\end{tabular}

Source: Lviv Polytechnic National University Institutional Repository http://ena.lp.edu.ua

Table 2 showed the level of $\mathrm{Cr}, \mathrm{Pb}, \mathrm{Ni}$ and $\mathrm{Cd}$ in the soil from $0-100 \mathrm{~m}$ depth in Ewekoro North east. Compared with $0-20 \mathrm{~cm}$ away from the cement factory at Ewekoro
North East during dry and seasons, $\mathrm{Cr}$ and $\mathrm{Pb}$ contents in the soil were significantly reduced while there were no significance differences in the amount of $\mathrm{Ni}$ and $\mathrm{Cd}$ up to 
$120 \mathrm{~cm}$ depth. It was noticed that $\mathrm{Cr}, \mathrm{Pb}, \mathrm{Ni}$ and $\mathrm{Cd}$ decreased as the soil depth increased. In Ewekoro the major difference in heavy metals status was that the data recorded in the wet season were higher than the data obtained in the dry season.

Also, table 1 showed the effect of cement particulateon properties of heavy metals in Ewekoro north east direction during dry and wet seasons. Compare with $500 \mathrm{~cm}$ distance away from the cement factory, the $\mathrm{Cr}$ content was significantly different from 1000, 1500 and $2000 \mathrm{~m}$ away from the factory while $\mathrm{Pb}, \mathrm{Ni}$ and $\mathrm{Cd}$ were significantly reduced except $1000 \mathrm{~m}$ away from the factory during the dry season. During the wet season, $\mathrm{Cr}, \mathrm{Pb}$ and $\mathrm{Ni}$ were significantly increased except $2000 \mathrm{~m}$ away from the factory. The $\mathrm{Cd}$ level was undetected. The $\mathrm{Pb}, \mathrm{Ni}, \mathrm{Cr}$ and $\mathrm{Cd}$ concentration in the oil did not follow the same pattern.
In Ewekoro south west, during the dry and wet seasons, there were no much significant difference s between $\mathrm{Cr}$ and $\mathrm{Pb}$ from $0-20 \mathrm{~cm}$ to $100-120 \mathrm{~cm}$ depth. During the dry season, $\mathrm{Ni}$ and $\mathrm{Cd}$ were not detected. Cadmium was not detected in Ewekoro south west during the wet season.

Compared with 500m distance away from the factory, there was increase in $\mathrm{Cr}$ content as the distance increased from 1000 to $2000 \mathrm{~m}$ distance. $\mathrm{Pb}$ (except 500m), $\mathrm{Ni}$ and $\mathrm{Cd}$ were not detected during the dry season. During the wet season, compared with $\mathrm{Cr}, \mathrm{Pb}$ and $\mathrm{Ni}$ at $500 \mathrm{~m}$ distance away from the factory, the $\mathrm{Cr}, \mathrm{Pb}$ and $\mathrm{Ni}$ increased as the distance increased except the $\mathrm{Cr}$ and $\mathrm{Pb}$ content at $1000 \mathrm{~m}$ away from the factory. The $\mathrm{Cr}, \mathrm{Pb}$ and $\mathrm{Ni}$ contents in wet season were higher than the $\mathrm{Cr}, \mathrm{Pb}$ and $\mathrm{Ni}$ during the dry season. Cadmium content was not detected.

Table 2: Impact of Cement Production on soil Chromium, lead, Nickel and Cadmium at Ewekoro cement factory within $2 \mathrm{~km}$ radius

EWEKORO NORTHEAST(Dry)
EWEKORO NORTH-

EAST(Wet)

\begin{tabular}{|l|llcl|c|cccc|}
\hline Depth & \multicolumn{1}{|c}{$\mathrm{Cr}$} & \multicolumn{1}{c}{$\mathrm{Pb}$} & $\mathrm{Ni}$ & \multicolumn{1}{c|}{$\mathrm{Cd}$} & Depth & $\mathrm{Cr}$ & $\mathrm{Pb}$ & $\mathrm{Ni}$ & $\mathrm{Cd}$ \\
\hline $0-20$ & $1.4275^{\mathrm{a}}$ & $1.74^{\mathrm{a}}$ & $0.15875^{\mathrm{a}}$ & $0.03^{\mathrm{a}}$ & $0-20$ & $1.63125^{\mathrm{a}}$ & $1.07375^{\mathrm{a}}$ & $0.15625^{\mathrm{a}}$ & $0^{\mathrm{a}}$ \\
$20-40$ & $1.335^{\mathrm{a}}$ & $1.4913^{\mathrm{ab}}$ & $0.12375^{\mathrm{a}}$ & $0.03125^{\mathrm{a}}$ & $20-40$ & $1.58125^{\mathrm{b}}$ & $1.05 \mathrm{a}^{\mathrm{b}}$ & $0.15625^{\mathrm{a}}$ & $0^{\mathrm{a}}$ \\
$40-60$ & $1.20875^{\mathrm{b}}$ & $1.4238^{\mathrm{ab}}$ & $0.12375^{\mathrm{a}}$ & $0.025^{\mathrm{a}}$ & $40-60$ & $1.54375^{\mathrm{bc}}$ & $1.01375^{\mathrm{b}}$ & $0.1425^{\mathrm{a}}$ & $0^{\mathrm{a}}$ \\
$60-80$ & $1.2125^{\mathrm{b}}$ & $1.3263^{\mathrm{b}}$ & $0.11125^{\mathrm{a}}$ & $0.03625^{\mathrm{a}}$ & $60-80$ & $1.55375^{\mathrm{bc}}$ & $0.94375^{\mathrm{c}}$ & $0.14125^{\mathrm{a}}$ & $0^{\mathrm{a}}$ \\
$80-100$ & $1.11125^{\mathrm{b}}$ & $1.3063^{\mathrm{b}}$ & $0.11875^{\mathrm{a}}$ & $0.02125^{\mathrm{a}}$ & $80-100$ & $1.57625^{\mathrm{b}}$ & $0.9225^{\mathrm{c}}$ & $0.11625^{\mathrm{b}}$ & $0^{\mathrm{a}}$ \\
$100-120$ & $1.10125^{\mathrm{b}}$ & $1.1375^{\mathrm{b}}$ & $0.075^{\mathrm{a}}$ & $0.0175^{\mathrm{a}}$ & $100-120$ & $1.525^{\mathrm{c}}$ & $0.87^{\mathrm{d}}$ & $0.05^{\mathrm{c}}$ & $0^{\mathrm{a}}$ \\
\hline
\end{tabular}

\begin{tabular}{|c|c|c|c|c|c|c|c|c|c|}
\hline Distance & $\mathrm{Cr}$ & $\mathrm{Pb}$ & $\mathrm{Ni}$ & $\mathrm{Cd}$ & Distance & $\mathrm{Cr}$ & $\mathrm{Pb}$ & $\mathrm{Ni}$ & $\overline{\mathrm{Cd}}$ \\
\hline 500 & $1.33^{\mathrm{b}}$ & $2.2658^{\mathrm{a}}$ & $0.18^{\mathrm{a}}$ & $0.05417^{\mathrm{a}}$ & 500 & $1.44917^{\mathrm{c}}$ & $0.93333^{\mathrm{b}}$ & $0.105833^{c}$ & $0^{\mathrm{a}}$ \\
\hline 1000 & $1.6375^{\mathrm{a}}$ & $2.0608^{\mathrm{a}}$ & $0.24417^{\mathrm{a}}$ & $0.04833^{\mathrm{a}}$ & 1000 & $2.1^{\mathrm{a}}$ & $1.29917^{\mathrm{a}}$ & $0.124167^{b}$ & $0^{\mathrm{a}}$ \\
\hline 1500 & $0.84167^{\mathrm{d}}$ & $0.3125^{\mathrm{c}}$ & $0^{\mathrm{b}}$ & $0^{\mathrm{b}}$ & 1500 & $1.49167^{\mathrm{b}}$ & $0.78833^{\mathrm{c}}$ & $0.095^{\mathrm{c}}$ & $0^{\mathrm{a}}$ \\
\hline 2000 & $1.12167^{c}$ & $0.9775^{\mathrm{b}}$ & $0.05^{\mathrm{b}}$ & $0.0005^{\mathrm{b}}$ & 2000 & $1.23333^{\mathrm{d}}$ & $0.895^{\mathrm{b}}$ & $0.183333^{\mathrm{a}}$ & $0^{\mathrm{a}}$ \\
\hline
\end{tabular}

EWEKORO SOUTHWEST(Dry)
EWEKORO SOUTHWEST(Wet)

\begin{tabular}{|c|c|c|c|c|c|c|c|c|c|}
\hline Depth & $\mathrm{Cr}$ & $\mathrm{Pb}$ & $\mathrm{Ni}$ & $\mathrm{Cd}$ & Depth & $\mathrm{Cr}$ & $\mathrm{Pb}$ & $\mathrm{Ni}$ & $\mathrm{Cd}$ \\
\hline $0-20$ & $0.19^{a}$ & $0.01^{\mathrm{ab}}$ & $0^{\mathrm{a}}$ & $0^{\mathrm{a}}$ & $0-20$ & $2.885^{a}$ & $7.035^{\mathrm{a}}$ & $0.20375^{a}$ & $0^{\mathrm{a}}$ \\
\hline $20-40$ & $0.2025^{\mathrm{a}}$ & $0.01^{\mathrm{ab}}$ & $0^{\mathrm{a}}$ & $0^{\mathrm{a}}$ & $20-40$ & $2.6638^{\mathrm{ab}}$ & $6.065^{\mathrm{a}}$ & $0.16^{\mathrm{b}}$ & $0^{\mathrm{a}}$ \\
\hline $40-60$ & $0.1925^{\mathrm{a}}$ & $0.0125^{\mathrm{a}}$ & $0^{\mathrm{a}}$ & $0^{\mathrm{a}}$ & $40-60$ & $2.3775^{\mathrm{b}}$ & $5.713^{\mathrm{a}}$ & $0.11375^{\mathrm{c}}$ & $0^{\mathrm{a}}$ \\
\hline $60-80$ & $0.18875^{\mathrm{a}}$ & $0.00375^{\mathrm{ab}}$ & $0^{\mathrm{a}}$ & $0^{\mathrm{a}}$ & $60-80$ & $2.4788^{a b}$ & $5.674^{\mathrm{a}}$ & $0.0925^{\mathrm{cd}}$ & $0^{\mathrm{a}}$ \\
\hline $80-100$ & $0.18^{a}$ & $0.0025^{\mathrm{ab}}$ & $0^{\mathrm{a}}$ & $0^{\mathrm{a}}$ & $80-100$ & $2.7088^{a b}$ & $7.119^{a}$ & $0.07^{\mathrm{d}}$ & $0^{\mathrm{a}}$ \\
\hline
\end{tabular}


International Journal of Environment, Agriculture and Biotechnology, 5(5)

Sep-Oct, 2020 / Available: https://ijeab.com/

\begin{tabular}{|c|cccc|c|ccccc|}
$100-120$ & $0.22875^{\mathrm{a}}$ & $0^{\mathrm{b}}$ & $0^{\mathrm{a}}$ & $0^{\mathrm{a}}$ & $100-120$ & $2.6038^{\mathrm{ab}}$ & $5.529^{\mathrm{a}}$ & $0.07625^{\mathrm{d}}$ \\
\hline Distance & $\mathrm{Cr}$ & $\mathrm{Pb}$ & $\mathrm{Ni}$ & $\mathrm{Cd}$ & Distance & $\mathrm{Cr}$ & $\mathrm{Pb}$ & $\mathrm{Ni}$ & $\mathrm{Cd}$ \\
\hline 500 & $0.11083^{\mathrm{b}}$ & $0.025833^{\mathrm{a}}$ & $0^{\mathrm{a}}$ & $0^{\mathrm{a}}$ & 500 & $1.4^{\mathrm{c}}$ & $4.0125^{\mathrm{b}}$ & $0.20417^{\mathrm{a}}$ & $0^{\mathrm{a}}$ \\
1000 & $0.27083^{\mathrm{a}}$ & $0^{\mathrm{b}}$ & $0^{\mathrm{a}}$ & $0^{\mathrm{a}}$ & 1000 & $0.9425^{\mathrm{d}}$ & $3.35^{\mathrm{b}}$ & $0.16167^{\mathrm{b}}$ & $0^{\mathrm{a}}$ \\
1500 & $0.14417^{\mathrm{b}}$ & $0^{\mathrm{b}}$ & $0^{\mathrm{a}}$ & $0^{\mathrm{a}}$ & 1500 & $5.13^{\mathrm{a}}$ & $8.6892^{\mathrm{a}}$ & $0.05417^{\mathrm{c}}$ & $0^{\mathrm{a}}$ \\
2000 & $0.2625^{\mathrm{a}}$ & $0^{\mathrm{b}}$ & $0^{\mathrm{a}}$ & $0^{\mathrm{a}}$ & 2000 & $3.0058^{\mathrm{b}}$ & $8.7042^{\mathrm{a}}$ & $0.0575^{\mathrm{c}}$ & $0^{\mathrm{a}}$ \\
\hline
\end{tabular}

Means with the same letter in the same column are not significantly different at 5\% level using Duncan multiple range test

\section{Effect of cement particulate on the nutrients status of the elephant grass (Pennisetum purpureum) at the vicinity of Ewekoro cement factory}

Tables 3 -6 showed the nutrients uptake of elephant grass (Pennisetum purpureum) in the vicinity of Ewekoro factory in the wet and dry seasons. The $\mathrm{N}, \mathrm{P}, \mathrm{Ca}, \mathrm{Mg}, \mathrm{Na}, \mathrm{Cu}$ and $\mathrm{Zn}$ concentration in Pennisetum purpureum harvested at the south west direction of Ewekoro cement factory during the wet season is shown in Table 3. Generally, it was observed that all the nutrients were reduced in concentration as the distance from the factory increased. Phosphorus (P), K, Ca,
$\mathrm{Mg}$ and $\mathrm{Na}$ (except $2000 \mathrm{~m}$ away) significantly increased as the distance from the factory reduced when compared with $2000 \mathrm{~m}$ away from the factory while there were no significant differences among $\mathrm{N}, \mathrm{Cu}$ and $\mathrm{Zn}$ when the distances were compared. The nutrients were adequate for optimum growth of Pennisetum purpureum. The nutrients composition of Pennisetum purpurem in the dry season followed the same trend as that of the wet season except that the concentrations were much lower in the dry season than the wet season (Table 4)

Table 3: Nutrients assessment of Pennisetum purpureum at the South-West direction of Ewekoro in the wet season

\begin{tabular}{|c|c|c|c|c|c|c|c|c|}
\hline \multirow{2}{*}{$\begin{array}{l}\text { Distance } \\
(\mathrm{Km})\end{array}$} & \multirow{2}{*}{$\begin{array}{l}\% \\
\mathrm{~N}\end{array}$} & \multicolumn{7}{|c|}{ 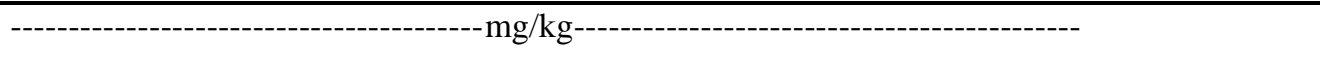 } \\
\hline & & $\mathrm{P}$ & $\mathrm{K}$ & $\mathrm{Ca}$ & $\mathrm{Mg}$ & $\mathrm{Na}$ & $\mathrm{Cu}$ & $\mathrm{Zn}$ \\
\hline 500 & $2.47^{\mathrm{a}}$ & $919.14^{\mathrm{a}}$ & $16310.26^{\mathrm{a}}$ & $45976.50^{\mathrm{b}}$ & $6321.38^{\mathrm{a}}$ & $1915.73^{\mathrm{a}}$ & $24.50^{\mathrm{a}}$ & $107.94^{\mathrm{a}}$ \\
\hline 1000 & $2.14^{\mathrm{a}}$ & $781.85^{\mathrm{b}}$ & $15391.23^{\mathrm{a}}$ & $46265.70^{\mathrm{a}}$ & $5880.14^{\mathrm{b}}$ & $1816.27^{\mathrm{b}}$ & $20.80^{\mathrm{a}}$ & $105.04^{\mathrm{a}}$ \\
\hline 1500 & $1.92^{\mathrm{a}}$ & $707.00^{\mathrm{c}}$ & $14983.07^{\mathrm{b}}$ & $42960.20^{c}$ & $5669.50^{\mathrm{c}}$ & $1793.22^{\mathrm{c}}$ & $20.15^{\mathrm{a}}$ & $100.60^{\mathrm{a}}$ \\
\hline 2000 & $1.52^{\mathrm{a}}$ & $673.79^{d}$ & $14085.72^{\mathrm{c}}$ & $40526.70^{d}$ & $4524.00^{\mathrm{d}}$ & $1757.62^{c}$ & $18.91^{\mathrm{a}}$ & $94.28^{\mathrm{a}}$ \\
\hline
\end{tabular}

Means with the same letter in the same column are not significantly different at 5\% level using Duncan multiple range test

Table 4: Nutrients assessment of Pennisetum purpureum at the South-West direction of Ewekoro in the dry season

$\begin{array}{lllllllll}\text { Distance } & \mathrm{N} & \mathrm{P} & \mathrm{K} & \mathrm{Ca} & \mathrm{Mg} & \mathrm{Na} & \mathrm{Cu} & \mathrm{Zn}\end{array}$


$(\mathrm{m})$

$$
\% \quad \mathrm{mg} / \mathrm{kg}
$$

$\mathrm{mg} / \mathrm{kg}$

$\mathrm{mg} / \mathrm{kg}$

$\begin{array}{lllllllll} & \% & \mathrm{mg} / \mathrm{kg} & & \mathrm{mg} / \mathrm{kg} & & & \mathrm{mg} / \mathrm{kg} & \\ 500 & 1.91^{\mathrm{a}} & 561.48^{\mathrm{a}} & 14353.5^{\mathrm{a}} & 39947.6^{\mathrm{a}} & 4557.85^{\mathrm{a}} & 1677.9^{\mathrm{a}} & 17.63^{\mathrm{a}} & 85.08^{\mathrm{a}} \\ 1000 & 1.71^{\mathrm{a}} & 566.07^{\mathrm{a}} & 14180.4^{\mathrm{a}} & 38201.5^{\mathrm{b}} & 4093.5^{\mathrm{c}} & 1665.2^{\mathrm{a}} & 17.31^{\mathrm{a}} & 79.76^{\mathrm{a}} \\ 1500 & 1.40^{\mathrm{a}} & 519.39^{\mathrm{b}} & 13209.9^{\mathrm{b}} & 35537.6^{\mathrm{c}} & 3596.67^{\mathrm{b}} & 1517.7^{\mathrm{b}} & 12.77^{\mathrm{a}} & 70.45^{\mathrm{a}} \\ 2000 & 1.44^{\mathrm{a}} & 509.63^{\mathrm{c}} & 10128.0^{\mathrm{c}} & 29935.2^{\mathrm{d}} & 3898.97^{\mathrm{b}} & 1412.8^{\mathrm{c}} & 13.12^{\mathrm{a}} & 62.00^{\mathrm{a}}\end{array}$

Means with the same letter in the same column are not significantly different at $5 \%$ level using Duncan multiple range test

Compared with $2000 \mathrm{~m}$ away from the factory, the $\mathrm{N}, \mathrm{P}, \mathrm{K}, \mathrm{Ca}$ and $\mathrm{Mg}$ contents of the leaves of Purpureum were significantly increased at 1500,1000 and $500 \mathrm{~m}$ distance away from the factory from the North east direction (Table 5). The N, P, K, Ca, Mg Na, Cu and $\mathrm{Zn}$ were reduced as the distance from the factory increased. The total $\mathrm{N}, \mathrm{K}, \mathrm{Ca}$ and $\mathrm{Mg}$ were adequate for proper growth of elephant grass up to $2000 \mathrm{~m}$ away from the factory (Tables 5 and 6). The available $\mathrm{P}$ was very low at any distance from the factory. All the nutrients contents in the plants sampled during the dry season were generally higher than the plants analyzed during the wet season (Table 6). There were no significant differences in $\mathrm{N}$ content of the sampled elephant grass at any distance from the factory.

\begin{tabular}{|c|c|c|c|c|c|c|c|c|}
\hline Distance (m) & \multicolumn{2}{|l|}{$\%$} & \multicolumn{6}{|c|}{ mg/kg } \\
\hline 1000 & $1.31^{\mathrm{b}}$ & $494^{\mathrm{a}}$ & $9490^{\mathrm{b}}$ & $35439^{b}$ & $3205^{b}$ & $1617^{\mathrm{b}}$ & $17^{\mathrm{a}}$ & $72^{\mathrm{a}}$ \\
\hline 1500 & $1.67^{\mathrm{a}}$ & $441^{\mathrm{b}}$ & $9225^{\mathrm{c}}$ & $34964^{\mathrm{c}}$ & $3100^{c}$ & $1608^{c}$ & $12^{\mathrm{b}}$ & $65^{\mathrm{b}}$ \\
\hline
\end{tabular}

Table 5: Nutrients assessment of Pennisetum purpureum at the North-East of Ewekoro in the wet season

Means with the same letter in the same column are not significantly different at $5 \%$ level using Duncan multiple range test

\begin{tabular}{|c|c|c|c|c|c|c|c|c|}
\hline \multirow{2}{*}{$\begin{array}{l}\text { Distance } \\
\text { (m) }\end{array}$} & \multirow[t]{2}{*}{$\mathrm{N} \%$} & \multirow[b]{2}{*}{$\mathrm{P}$} & \multicolumn{6}{|c|}{-----------------------------(mg/kg)------------------------------ } \\
\hline & & & $\mathrm{K}$ & $\mathrm{Ca}$ & $\mathrm{Mg}$ & $\mathrm{Na}$ & $\mathrm{Cu}$ & $\mathrm{Zn}$ \\
\hline 500 & $1.43^{\mathrm{a}}$ & $1133^{\mathrm{a}}$ & $13412^{\mathrm{b}}$ & $51288^{\mathrm{a}}$ & $4878^{\mathrm{a}}$ & $2444^{\mathrm{a}}$ & $34^{\mathrm{a}}$ & $129^{a}$ \\
\hline 1000 & $1.31^{\mathrm{a}}$ & $1097^{\mathrm{b}}$ & $12716^{\mathrm{a}}$ & $49521^{\mathrm{b}}$ & $4600^{\mathrm{b}}$ & $2404^{\mathrm{b}}$ & $29^{\mathrm{b}}$ & $118^{\mathrm{b}}$ \\
\hline 1500 & $1.26^{\mathrm{a}}$ & $1050^{\mathrm{c}}$ & $12339^{\mathrm{b}}$ & $48205^{\mathrm{c}}$ & $4173^{c}$ & $2212^{c}$ & $25^{\mathrm{b}}$ & $104^{\mathrm{c}}$ \\
\hline 2000 & $1.36^{\mathrm{a}}$ & $992^{\mathrm{d}}$ & $10623^{c}$ & $44895^{d}$ & $3576^{d}$ & $2107^{d}$ & $25^{b}$ & $104^{\mathrm{c}}$ \\
\hline
\end{tabular}

Table 6: Nutrients assessment of Pennisetum purpureum at the North East direction of Ewekoro in the dry season

Means with the same letter in the same column are not significantly different at $5 \%$ level using Duncan multiple range test

Compared the nutrient contents of the sampled in the west direction to the east direction, the $\mathrm{N}, \mathrm{K}, \mathrm{Ca}$ and $\mathrm{Mg}$ contents of the plants in west direction was higher than the north east direction. The $\mathrm{P}, \mathrm{Na}, \mathrm{Cu}$ and $\mathrm{Zn}$ contents in the north east direction was higher than the west direction. 


\section{DISCUSSION}

The heavy metal Nickel (Ni) in the sampled soils was low, going by MAFF (1992) recommendation of $50 \mathrm{mg} / \mathrm{kg}$ for $\mathrm{Ni}$ as its critical level while Lead $(\mathrm{Pb})$ concentration in the soil was above $0.01 \mathrm{mg} / \mathrm{L}$ recommended by WHO (1984). At present, Ni might not pose negative effect on crops grown in the area while the concentration of $\mathrm{Pb}$ needs to be put in check. Alloway (1995) observed that the crop grown in polluted area can absorb heavy metals in excess that are likely to pose risk to human health. This work is in line with Adejumo et al., (1994); Schuhmacher et al., (2004); AlKhashman and Shawabkeh, (2006); Isikli et al., (2006) who stated that cement production emits heavy metals such as $\mathrm{Cd}$, $\mathrm{Cr}, \mathrm{Cu}, \mathrm{Pb}$ and $\mathrm{Zn}$. Lepedus et al., (2003) emphasized that cement dust during cement processing can reduce chlorophyll and carotenoid content. Studies on the effect of cement dust on biosynthetic processes in the plant by Oyedele et al. (1995) also revealed a reduction in chlorophyll and carotenoid content, impair Carbon IV Oxide exchange and reduction in plant photosynthesis rate. Also, Oyedele et al., 1995; Schuhmacher et al., 2004; Al-Khashman and Shawabkeh, 2006; Isikli et al., 2006 buttressed that Cement production emits heavy metals such as $\mathrm{Cd}, \mathrm{Cr}, \mathrm{Cu}, \mathrm{Pb}$ and $\mathrm{Zn}$ which are deposited into the soil and thereafter absorbed by plants . Achternbosch et al. (2003) reported that conventional cement raw materials contain $25 \mathrm{mg} / \mathrm{kg}$ of $\mathrm{Cr}$, $21 \mathrm{mg} / \mathrm{kg}$ of $\mathrm{Cu}, 20 \mathrm{mg} / \mathrm{kg}$ of $\mathrm{Pb}$ and $53 \mathrm{mg} / \mathrm{kg}$ of $\mathrm{Zn}$ and about $50 \%$ of the total, $\mathrm{Cd}, \mathrm{Cu}$ and $\mathrm{Zn}$ load in cement ranked highest. This might be the reason why the soils around the cement factory in Ewekoro are high in $\mathrm{Fe}, \mathrm{Zn}, \mathrm{Pb}$ and $\mathrm{Cr}$. Josephine et al, (2017) were of the opinion that majority of the emitted heavy metals are known to be toxic to humans and plants, even at low concentrations. Murugesan et al., 2004 observed that cement kiln exhaust of the cement factory deposits on vegetables could be absorbed by plants and have adverse effect on human health when the plants are consumed. The $\mathrm{Ca}$ and $\mathrm{Mg}$ contents in the elephant grass were found to be high. This is in agreement with the assertion of Farmer (1993), that, the alkaline cement dust and their ash in the pollution complex lead to increase in soil alkalinity.

The high $\mathrm{N}$ content obtained in the elephant grass in this work in the dry season was higher than that reported for $\mathrm{N}$ in the dry season. This might be as a result of moisture that enhanced $\mathrm{N}$ nitrification. High rates of $\mathrm{Ca}$ is known to be inversely related to the phosphorus content in soil and it is even known to inhibit the absorption and utilization of $\mathrm{P}$ and other nutrient elements in the soil.

Also $\mathrm{Cu}$ and $\mathrm{Zn}$ in both locations and both seasons exceeded the World Health Organization (WHO) recommended value limit of 10 and $50 \mathrm{mgkg}^{-1}$ in plants. This is likely to have negative impact on animals that feed on them. There was no particular trend observed in the nutrient content of elephant grass with regard to the distance to the cement manufacturing factory for $\mathrm{N}, \mathrm{P}, \mathrm{K}, \mathrm{Ca}, \mathrm{Mg}, \mathrm{Na}, \mathrm{Cu}$ and $\mathrm{Zn}$ contents. . Accumulation of heavy metals by plants' roots, stems and leaves grown in polluted soils have been reported severally. Okoronkwo et al. (2005) said that it had been the interest of the public to know whether vegetables, fruits and other food crops cultivated in polluted soils are safe for human consumption especially now that the environmental quality of food production is of significant concern (Chiroma et al., 2003). The understanding of the behaviour of contaminants especially heavy metal in the soil-plant system seems to be particularly significant. For instance, consumption of $\mathrm{Pb}$ is believed to cause mental retardation in many children, while mild consumption causes anaemia (Bladwin and Marshall (1999).). Toxic elements are taken in through air, food and water. Out of these three, the air intake is the most readily assimilated into the body (Rai et al, 2010).

\section{CONCLUSION}

The study investigated the impact of cement production on physicochemical properties of soils and Elephant grass grown around Ewekoro cement factory. in Ogun state, SW Nigeria within two-kilometer radius to the factories between 2015 and 2016

The research presented in this work revealed that the cement industry is one of the polluting industries. Controlling the spread of dust and other emissions should be given top priority to maintain the ecosystem around the vicinity of the factory.

\section{REFERENCES}

[1] Achternbosch M, Bra ütigam KR, Hartlieb N, Kupsch C,Richers U, Stemmermann P (2003). Heavy metals in cement and concrete resulting from the co-incineration of wastes in cement kilns with regard to the legitimacy of waste utilisation. Karlsruhe: Forschungszentrum Karlsruhe $\mathrm{GmbH}$

[2] A.O.A.C. (1970). Official methods of analysis $11^{\text {th }}$ ed. Association of Official Analytical Chemist, Washington DC. 
[3] Al- Khashman, O.A. and Shawabkeh, R. A. (2006). Metals Distribution in Soils Around the Cement Factory in Southern Jordan. Environment Pollution 140: 387.

[4] Alloway, B. J. (1995). Heavy metals in soils $2^{\text {nd }}$ Ed. Blakie Academic and Professionals, London. UK. p.190.

[5] Bladwin, D. R. and Marshall, W. J. (1999). Heavy metal poisoning and its laboratory investigation. Journal of Clinical Biochemistry 36 (3): 267- 300.

[6] Blacksmith Institute (2007). The world's most polluted places. Blacksmith Institute.

[7] Bremmer (1996). Comparison of Total Nitrogen Methods Applied for Histosols and Soil Horizons with High organic Matter Content. In Communications in Soil and Plant Analysis. 37: 939-943

[8] CABI (2014). Invasive species compendium datasheets of Elephant grass (Pennisetum purpureum). Wallingford (UK): CAB International.

[9] Chapman, D. and Kimstach, V. (1996). Selection of Water Quality Variables. In Water Quality Assessments - A Guide to Use of Biota, Sediments and Water in Environmental Monitoring. Ed. Deborah Chapman. 2nd Edition. UNESCO/WHO/UNEP. Pp 74-89

[10] Chapman, D. and Pratt (1961). Direct and residual effects of plant growth retardants, on cotton seed. In Agricultural Sciences. 4 (12A)

[11] Chiroma T.M, Ebewele, R.O and Hymore F.K..(2012). Levels of Heavy Metals $(\mathrm{Cu}, \mathrm{Zn}, \mathrm{Pb}, \mathrm{Fe}$ and $\mathrm{Cr})$ in Bushgreen and Roselle Irrigated with Treated and Untreated Urban Sewage Water. International Research Journal of Environmental Sciences. 1(4): 50-55.

[12] FAO, (2015). Grazing management and tussock distribution in elephant grass: In Grass and Forage Science. 70 (3): 214215

[13] Farmers, (1993). Effects of Riyadh cement industry pollutions on some physiological and morphological. In Saudi Journal of Biological Sciences.

[14] FMANR, (1990). Literature review on soil fertility investigations in Nigeria. Federal Ministry of Agriculture and Natural Resources, Lagos, pp: 32-45.

[15] Isikli et al., (2006). Distribution and variation of Heavy metals and soil properties around mega a cement factory in Gboko, Benue state, Nigeria. International Journal of Science and Technology. 4 (7): $2-17$

[16] Josephine Adekola, Moira Fischbacher-Smith, Denis Fischbacher and Olalekan Adekola. (2017): Health Risks from Environmental Degradation in the Niger Delta, Nigeria. Environmental and Planning. 35 (2): 334-354

[17] Larcher (1995). Physiological Plant Ecology $3^{\text {rd }}$ Edition.Published by Berlin Heidelberg New York.springerVerlag, 1995. (1995). ISBN 10:0387581162/ISBN 13:9780387581163

[18] Lepedus, H., Cesar, V and Suver, M. (2003). The annual changes or chloroplast pigment content in current and previous year needles or Norway spruce (Picea abies L. Karst) exposed to cement dust pollution. ACTA Botanica Croatica 62: $27-35$.

[19] MAFF, 1992. Code of Good Agricultural Practice for the Protection of Air. MAFF, London, UK., pp: 87-153

[20] Murphy J. and Piley J.P., (1962). A modified single solution methods for the determinants of phosphate in natural waters. Analytical Chem. Acta 27: 31-6, 1962.

[21] Murugesan, M., A. Sivakumar, N. Jayanthi and K. Manonmani (2004). Effect of cement dust pollution on physiological and biochemical activities of certain plants. Pollution Research. 23(2): 375-378.

[22] Okoronkwo, N.E. Igwe J. C. \& Onwuchekwa E.C. (2005). Risk and health implications of polluted soils for crop production: African Journal of Biotechnology. 4:1521-1524.

[23] Oyedele, D. J., Obioh, I. B., Adejumo, J. A., Oluwole, A. F., Aina, P. O \& Asubiojo, O. I. (1995). Lead contamination of soils and the vegetation in the vicinity of lead smatter in Nigeria. The Science of the total Envir,lfyioubbvnuycuctyuconment. 172 (2-3): 189-195.

[24] Samal A. \&Santra, M. (2002). Particulate matter effect on biometric and biochemical attributes of fruiting plants. Global Journal of Environmental Science and Management.

[25] Schuhmacher, M., Domingo J. L. \& Garreta J. (2004). Pollutants emitted by a cement plant: Health risks for the population living in the neighbourhood. In Environmental Research 95(2) 198 - 206.

[26] Rai, A. Kulshreshtha, K. Srivastava, P.K \& Mohanty, C.S (2010): Leaf surface structure alterations due to particulate pollution in some common plants. Environmentalist. 30, 1823.

[27] WHO (IPCS) (1983) Environmental Health Criteria 27: Guidelines on Studies in Environmental Epidemiology. WHO, Geneva. Pp. 351 